\title{
Czy embrion jest osobą? Spór o sztuczne zapłodnienie we Włoszech
}

Obecnie w wielu krajach wzrasta skala stosowania metod sztucznego zapłodnienia, zwanego także rozrodem wspomaganym lub zapłodnieniem pozaustrojowym. W związku z tym, że niepłodność małżeńska staje się prawdziwą plagą społeczną, można oczekiwać, że w najbliższej przyszłości różnego rodzaju techniki rozrodu wspomaganego będą znajdować coraz więcej zwolenników. Nie ulega wątpliwości, że wykorzystanie metod sztucznego zapłodnienia budzi poważne kontrowersje natury moralnej. W konsekwencji w wielu społeczeństwach toczą się trudne debaty światopoglądowe dotyczące etycznych i prawnych aspektów tego zjawiska. Szczególnie interesującym przypadkiem są Włochy, gdzie w sprawie zapłodnienia pozaustrojowego przeprowadzono w 2005 roku ogólnonarodowe referendum.

\section{Aspekty prawne rozrodu wspomaganego}

W większości krajów zachodnich przyjęto w ostatnich dziesięcioleciach bardzo precyzyjne rozwiązania prawne regulujące stosowanie metod sztucznego zapłodnienia. Włochy są jednym z ostatnich państw „starej” Unii Europejskiej, w którym uchwalono podobną ustawę. Prawo normujące wykorzystanie metod zapłodnienia pozaustrojowego weszło w życie 10 marca 2004 roku jako ustawa 40/2004. W ten sposób zaczęły obowiązywać zasady, które położyły kres tzw. Far West prokreacyjnemu. Należy zauważyć, że przyjęcie ustawy poprzedziła wieloletnia dyskusja parlamentarna oraz niezwykle ożywiona debata publiczna ${ }^{1}$.

Włoski spór wokół rozrodu wspomaganego dotyczy nie tylko kształtu proponowanych zapisów prawnych, ale także samej potrzeby tego rodzaju ustawy.

Por. C. Flamigni, La procreazione assistita, Bologna 2002, s. 118-122; C. Casalone, G. Formigoni, M. Picozzi, G. Tonini, La fecondazione assistita. Un dibattito aperto tra scienza, morale, diritto e politica, Milano 2005. 
Wielu naukowców, filozofów i prawników - banalizujących aspekty moralne zapłodnienia pozaustrojowego - sprzeciwia się jakiejkolwiek regulacji prawnej tego zjawiska. Dla ludzi prezentujących takie poglądy ważnym punktem odniesienia są opinie bioetyków laickich oraz wypowiedzi przedstawicieli organizacji feministycznych, którzy odrzucają potrzebę wszelkiego rodzaju ograniczeń prawnych w stosowaniu metod zapłodnienia pozaustrojowego.

Wydaje się, że wpływ włoskich kręgów feministycznych na poglądy społeczeństwa w omawianej sprawie nie jest zbyt duży. Gdy chodzi o myśl feministyczną, należy zauważyć radykalną zmianę tych środowisk w podejściu do sztucznego zapłodnienia, jaka nastąpiła w ostatnich latach. W przeszłości kręgi feministyczne prezentowały metody zapłodnienia pozaustrojowego jako drogę wyzwolenia z trudu macierzyństwa. Ostatnio część feministek opisuje tego rodzaju techniki jako narzędzia, przez które mężczyzna wyraża swoją zazdrość o kobiecą prokreację i usiłuje podporządkować sobie kobiety, pozbawiając je władzy nad ludzką rozrodczością. Dlatego sugeruje się kobietom sprzeciw wobec stosowania metod sztucznego zapłodnienia, aby w ten sposób nie tracić własnej władzy nad prokreacją $w$ wymiarze społecznym. W konsekwencji takiego rozumowania nie potrzeba regulacji prawnych rozrodu wspomaganego, ponieważ powinno w ogóle zniknąć zjawisko jako takie.

O wiele większy wpływ na kształt debaty we Włoszech mają szeroko prezentowane poglądy bioetyków laickich (H.T. Engelhardt, U. Scarpelli), którzy nie akceptują zasady nienaruszalności życia ludzkiego, opowiadając się za utylitarystycznie rozumianą zasadą jakości życia². W perspektywie bioetyków laickich początek życia ludzkiego w sensie biologicznym nie utożsamia się z początkiem życia osobowego. Zdaniem Engelhardta, w człowieku można wyróżnić trzy poziomy: życia biologicznego, życia umysłowego i życia osobowego. Aby można było mówić o istnieniu osoby ludzkiej, musi pojawić się wyższy poziom życia umysłowego. W konsekwencji ludzkie embriony nie mogą być traktowane jako osoby. Istoty, które posiadają tylko życie biologiczne, nie mają żadnej własnej wartości. Ich wartość określają osoby dorosłe, do których należą. W związku z tym są do ich dyspozycji aż do momentu, kiedy uzyskają samoświadomość.

$\mathrm{W}$ tej perspektywie sztuczne zapłodnienie, eksperymenty na embrionach, niszczenie embrionów nadliczbowych itp. powinny być pozostawione w sferze wolnych decyzji człowieka. To wszystko, co dotyczy życia w jego fazie początkowej należy wyłącznie do sfery autonomii jednostki. Zgodnie z tym paradygmatem myślowym zygoty i płody należą do nas i są przedłużeniem oraz owocem

Por. H.T. Engelhardt, Manuale di bioetica, Milano 1991, s. 248-249; Bioethics and Secular Humanism: the Serach for a Common Morality, London-Philadelphia 1991; U. Scarpelli, Bioetica: prospettive e principi fondamentali, w: M. Mori (Red.), La bioetica. Questioni morali e politiche per il futuro dell'uomo, Milano 1991, s. 20-25. 
naszego ciała. Pozostają do naszej dyspozycji, aż uzyskają panowanie nad sobą jako istoty świadome. W opinii bioetyków laickich jakiekolwiek regulacje prawne w tej dziedzinie stanowiłyby naruszenie autonomii osoby ${ }^{3}$.

W tym przypadku zasada autonomii zyskuje wymiar quasi totalitarny i niszczy każdą inną wartość moralną. Jeśli poddajemy ocenie np. zjawisko aborcji, zgodnie z takim sposobem myślenia nie istnieje nawet cień konfliktu moralnego: oto mamy osobę z określonymi prawami (matka) i istotę, która ma tylko życie biologiczne i nie posiada żadnych praw. W konsekwencji żadna ustawa nie powinna ingerować w autonomiczne decyzje kobiety odnoszące się do aborcji czy sztucznego zapłodnienia, ponieważ jakiekolwiek ograniczenia w tej sferze stanowiłyby zamach na autonomię jednostki i jej wolność.

Wydaje się, że podstawowy błąd bioetyki laickiej dotyczy koncepcji osoby. Dla zdecydowanej większości koncepcji filozoficznych - włączając także tę liberalną, na którą bioetyka laicka się powołuje - osoba ludzka charakteryzuje się tym, że posiada godność i prawa wrodzone, które nie muszą być nadawane przez żaden autorytet zewnętrzny. Nikt nie może być sędzią w sprawie osobowego charakteru istnienia drugiego człowieka. Wszyscy ludzie są osobami, niezależnie od stopnia ich rozwoju. Zasada autonomii stosowana przez silnych w stosunku do słabych naruszałaby ich prawa a nawet życie. Dlatego muszą istnieć ustawy, które w szczególny sposób staną na straży godności tych, którzy nie mogą bronić się sami. W tym kontekście prawo regulujące wykorzystanie technik rozrodu wspomaganego nie jest arbitralną decyzją władzy państwowej, ale przejawem troski o sprawiedliwość i szacunek dla każdej osoby ludzkiej.

W znakomitej większości państw europejskich zwyciężyło przekonanie, że stosowanie technik zapłodnienia pozaustrojowego wymaga regulacji prawnych. $\mathrm{Na}$ naszym kontynencie najbardziej liberalne przepisy w tej dziedzinie obowiązują w Wielkiej Brytanii i Hiszpanii. Z kolei Austria, Szwecja i Niemcy to kraje, w których prawo chroni ludzki embrion w największym stopniu. Pośrodku można umieścić Francję, która stała się inspiracją dla rozwiązań przyjętych ostatecznie we Włoszech ${ }^{4}$. Warto zauważyć, że w ostatnich latach w wielu państwach europejskich wprowadzono różnego rodzaju ograniczenia w stosowaniu metod zapłodnienia pozaustrojowego, ponieważ dostrzeżono ich negatywny wpływ na życie ludzkie, rodzinę i tkankę społeczną.

Prawo obowiązujące obecnie w Szwajcarii dotyka problemu w sposób minimalny, określając jedynie status dziecka poczętego. W Wielkiej Brytanii i Szwecji uchwalono natomiast ustawy, które w sposób fragmentaryczny regulują aspekty

\footnotetext{
3 Por. M. Aramini, La fecondazione artificiale. Che cosa dice la legge e che cosa insegna la Chiesa, Casale Monteferrato 2004, s. 27-34; S. Leone - S. Privitera, Bioetica, w: Tenże, Nuovo Dizionario di Bioetica, Roma 2004, s. 105-114.

4 Por. M. Aramini, dz. cyt., s. 35-45.
} 
uznane za najbardziej pilne. W Hiszpanii i Francji przyjęto ustawy normujące prezentowane zjawisko w sposób kompleksowy. Wszystkie państwa europejskie przewidują możliwość wykorzystania metod sztucznego zapłodnienia przez pary małżeńskie lub żyjące w konkubinacie. Wielka Brytania i Hiszpania dodają do tej grupy także kobiety niezamężne i wdowy, ponieważ nad prawem dziecka przeważyła zasad równości kobiet zamężnych i niezamężnych.

We wszystkich państwach dopuszcza się sztuczne zapłodnienie homologiczne i heterologiczne. Jedynym krajem, który całkowicie zakazuje rozrodu wspomaganego heterologicznego jest Szwecja. Niektóre ustawy wprowadzają różnego rodzaju ograniczenia odnośnie do stosowania technik heterologicznych, np. prawo francuskie zezwala na zapłodnienie pozaustrojowe heterologiczne tylko wtedy, gdy wcześniej przy prokreacji nie pomogły inne techniki medyczne. Natomiast Austria, Norwegia i Szwecja zakazują pobierania od dawczyń komórek jajowych.

$\mathrm{Z}$ zasady wszędzie jest dozwolone zamrażanie nasienia męskiego. W Austrii maksymalny czas przetrzymywania w takiej formie nasienia to dwa lata, w Wielkiej Brytanii - dziesięć. Wszystkie ustawy zakazują zamrażania zeńskich komórek rozrodczych, ponieważ nie ma wystarczających gwarancji, że rozmrożone komórki jajowe mogą być jeszcze wykorzystane do celów prokreacyjnych. Zamrażanie embrionów jest zasadniczo dozwolone najdłużej na pięć lat, z wyjątkiem Austrii (dwa lata) i Szwecji (rok). Eksperymenty na embrionach do 14. dnia życia są dozwolone w Hiszpanii, Wielkiej Brytanii i Szwecji, natomiast prawo niemieckie dopuszcza tego rodzaju eksperymenty do 22 godzin po poczęciu. W Niemczech uznano status prawny embrionu i zabezpieczono jego ochronę przed wszczepieniem do łona matki. Prawo francuskie zakazuje badań z wykorzystaniem embrionów. Wyjątkowo można wykorzystać embrion do eksperymentów medycznych, jeśli celem jest terapia ukierunkowana na korzyść embrionu. Wszystkie państwa europejskie zakazują tzw. macierzyństwa zastępczego. W znakomitej większości krajów prawo uznaje macierzyństwo matki, która urodziła dziecko, co kwestionuje jakąkolwiek moc prawną kontraktów dotyczących tzw. macierzyństwa zastępczego.

\section{Najważniejsze rozstrzygnięcia ustawy 40/2004}

Prawo przyjęte we Włoszech wprowadza kontrolę państwa nad wszystkimi ośrodkami zajmującymi się zapłodnieniem pozaustrojowym. Ustawa 40/2004 przewiduje, że wszystkie pary zamierzające wykorzystać techniki sztucznego zapłodnienia muszą być poinformowane o ich aspektach zdrowotnych, psychologicznych i etycznych. Fundament ustawy uchwalonej przez włoski parlament stanowi przekonanie, że człowiek jest zawsze człowiekiem od momentu poczęcia do śmierci. O uznaniu człowieczeństwa ludzkiego embrionu od momentu poczęcia mówi art. 1 prezentowanej ustawy, umieszczając dziecko poczęte wśród podmio- 
tów, którym należy zagwarantować prawa. To oznacza: a) że embrion jest bytem ludzkim; b) że jest nim na równi z matką, ojcem, lekarzem; c) że takie uznanie podmiotowości ludzkiej i prawnej rozpoczyna się w pierwszym momencie zapłodnienia. Tego rodzaju rozwiązanie prawne wypływa z przekonania, że od momentu poczęcia ludzki embrion posiada określoną tożsamość i własne DNA. W ten sposób rozpoczyna się jego stopniowy autonomiczny rozwój. W procesie rozwoju ludzkiego embrionu nie można wskazać, oczywiście poza chwilą poczęcia, żadnego innego momentu, który byłby „skokiem jakościowym” oznaczającym początek człowieczeństwa. Z tej fundamentalnej zasady człowieczeństwa dziecka poczętego wypływają trzy kryteria, które łączą się ze sobą i znajdują swój wyraz w ustawie $40 / 2004^{5}$.

Po pierwsze, prymat dziecka w stosunku do dorosłych. Tego rodzaju zasada została uroczyście ogłoszona w 1989 roku w Konwencji Prawa Dziecka. Mówi ona, że w każdej decyzji dotyczącej dorosłych i dzieci należy dać pierwszeństwo interesom dzieci. Po drugie, zasada równości. Wszyscy ludzie są równi pod względem godności. Odnosi się to także do życia ludzkiego w fazie embrionalnej. Istnieje moralny obowiązek, aby traktować ludzki embrion od momentu zapłodnienia zgodnie z zasadami szacunku i ochrony, które stosuje się w stosunku do jednostek ludzkich jako osób. Po trzecie, zasada ostrożności. W sytuacjach wątpliwych należy zastosować takie rozwiązania praktyczne, które mogą chronić życie, a nie takie, które będą je niszczyć. Zasada ostrożności jest powszechnie akceptowana $\mathrm{w}$ obszarze ekologii. Zgodnie $\mathrm{z}$ takim rozumowaniem nie wolno wprowadzać jakichkolwiek innowacji technologicznych czy genetycznych, jeśli nie ma pewności, że nie będą przynosić żadnych szkód.

Konsekwencją uznania osobowego charakteru dziecka poczętego jest zakaz jakichkolwiek form klonowania człowieka, produkowania ludzkich embrionów w celach naukowych, selekcji preimplantacyjnej, zamrażania i niszczenia ludzkich embrionów. Wiąże się z tym obowiązek powoływania do życia tylko tylu embrionów, ile potrzeba do wszczepienia do organizmu matki, ale nigdy więcej niż trzy dla każdej próby. Wszystkie powstałe embriony muszą być umieszczone bezpośrednio w macicy. Zamrożenie embrionów jest możliwe tylko w sytuacji wyższej konieczności, tzn. z powodu przyczyny, której nie można było przewidzieć w momencie zapłodnienia, np. gdyby nagle pogorszył się stan zdrowia matki. W tym przypadku zamrożenie embrionu jest jedynym sposobem ochrony poczętego życia, nawet jeśli wiemy, że zamrażanie i rozmrażanie embrionów prowadzi często do ich śmierci

Warto zauważyć, że niska skuteczność metod rozrodu wspomaganego prowadzi do wysokiego poziomu śmiertelności embrionów przed implantacją a także

5 Por. C. CAsini, Procreazione assistita. Introduzione alla nuova legge, Cinisello Balsamo 2004, s. 13-15. 
po wszczepieniu do organizmu matki. Ustawa 40/2004 próbuje uniemożliwić całkowicie straty embrionów na etapie przedimplantacyjnym oraz zapobiec takim działaniom jak np. redukcja płodowa, które prowadzą do unicestwienia dziecka w łonie matki. Oczywiście chodzi o przypadki śmierci embrionów, które weryfikują się nie w sposób naturalny, niezależny od człowieka, ale są bezpośrednio spowodowane jego działaniem. Wielką zasługą prawa włoskiego jest potwierdzenie prawa każdego ludzkiego embrionu do narodzin; także tej ludzkiej istoty, która została poczęta w probówce.

Ważnym elementem ustawy 40/2004 jest zakaz sztucznego zapłodnienia heterologicznego. Oczywiście w każdym społeczeństwie istnieją dzieci „naturalnie heterologiczne", będące owocem przypadkowych relacji seksualnych. Włoski parlament nie uznał jednak racji tych, którzy twierdzą, że przez imitację takiego faktu można uzasadnić rozród wspomagany heterologiczny. Zapłodnienie naturalne jest faktem prywatnym, który wymyka się spod jakiejkolwiek kontroli. Natomiast sztuczne zapłodnienie jest faktem wcześniej zaplanowanym o wymiarze społecznym. Ustawa 40/2004 eliminuje sytuacje, w których zostałaby naruszona relacja rodzice-dzieci; $w$ przypadkach ekstremalnych dziecko z probówki może mieć trzy matki (biologiczną, noszącą płód w swoim łonie, w sensie prawnym) oraz dwóch ojców (biologicznego i w sensie prawnym). Konsekwentnie prawo wprowadzone we Włoszech zakazuje stosowania technik zapłodnienia pozaustrojowego kobietom samotnym i parom homoseksualnym, a także zabrania tzw. macierzyństwa zastępczego i stosowania technik z wykorzystaniem nasienia zmarłego męża.

Ustawa 40/2004 zezwala na stosowanie technik rozrodu wspomaganego tylko jako extrema ratio, czyli jedynie wówczas, gdy nie można w jakikolwiek sposób usunąć przyczyn bezpłodności małżonków. Prawodawca ocenia adopcję jako rozwiązanie bardziej preferowane niż metody sztucznego zapłodnienia. Dlatego konsultanci medyczni są zobowiązani do informowania nie tylko o wszelkich aspektach zapłodnienia pozaustrojowego, ale także o wszystkich możliwych formach adopcji. Warto podkreślić, że prawo włoskie przewiduje także zasadę sprzeciwu sumienia, która daje lekarzom i pielęgniarkom prawo do powstrzymania się od udziału w zabiegach, których nie akceptują z przyczyn moralnych.

Wielu komentatorów wskazuje na zapisy ustawy 40/2004, które wymagają udoskonalenia ${ }^{6}$. Jednym z nich jest punkt dotyczący sytuacji embrionów, które nie mogą być umieszczone $w$ macicy $z$ powodu choroby matki. W ustawie przewiduje się wyzdrowienie matki i wszczepienie embrionu. Należy jednak przewidzieć sytuacje, kiedy choroba lub śmierć matki uniemożliwią na zawsze implantację zarodka. Ważnym problemem wymagającym wyjaśnienia jest także sprzeczność istniejąca między tzw. ustawą 194 z 1978 roku, która legalizuje

6 Por. M. Aramini, dz. cyt., s. 56-57. 
we Włoszech aborcję, a obecnym prawem dotyczącym sztucznego zapłodnienia. Prawna ochrona dziecka poczętego powinna dotyczyć wszystkich sytuacji. Nie może być tak, że jedna ustawa chroni ludzki embrion powstały na drodze zapłodnienia pozaustrojowego i mówi o jego podmiotowości, a druga zezwala na zabicie dziecka poczętego obecnego w łonie matki.

\section{Spór wokół referendum}

Trwająca od wielu lat ożywiona dyskusja społeczna na temat stosowania technik sztucznego zapłodnienia nie zakończyła się wraz z przyjęciem ustawy 40/2004. Wręcz przeciwnie; okazało się, że burzliwa ogólnonarodowa dyskusja rozpoczęła się dopiero w tym momencie. Zaraz po wejściu nowego prawa w życie jego przeciwnicy przystąpili do organizacji referendum w sprawie uchylenia obowiązującej ustawy. Warto podkreślić, że instytucja referendum we włoskim systemie politycznym została pomyślana jako korekta głosowania parlamentarnego w sytuacji, gdy nie odzwierciedla ono woli społeczeństwa. Zgodnie z takim rozumowaniem ustawa przyjęta przez parlament może zostać uchylona w całości lub częściowo, jeśli taką wolę wyrazi w głosowaniu większość obywateli. To oznacza, że organizatorzy referendum muszą przekonać połowę plus jeden mających czynne prawo wyborcze, aby udali się do urn i w większości zagłosowali za zniesieniem danej ustawy.

Promotorzy referendum zebrali wymagane 500 tys. podpisów i przystąpili do zmasowanej kampanii medialnej i edukacyjnej. Do udziału w referendum i głosowania na "tak" wzywały przede wszystkim środowiska lewicowe oraz najbardziej opiniotwórcze gazety. Główne sily wzywające do powstrzymania się od głosowania to Kościół katolicki oraz przedstawiciele środowisk konserwatywnych i prawicowych. Bardzo ciekawym zjawiskiem w kampanii referendalnej okazała się współpraca różnych grup społecznych opowiadających się za zachowaniem ustawy 40/2004. Niezwykle ważną rolę odegrał Komitet „Nauka \& Życie”, który powołano 23 lutego 2005 roku. Zrzeszał on bardzo wielu wybitnych intelektualistów reprezentujących różne środowiska naukowe, kulturalne i polityczne. Celem, który sobie postawiono, było przekonanie w debacie publicznej mieszkańców Włoch, aby powstrzymali się od udziału w referendum. Członkowie Komitetu tłumaczyli społeczeństwu swoje racje $w$ mediach, na konferencjach naukowych, podczas spotkań z mieszkańcami bardzo wielu miejscowości ${ }^{7}$.

Przeciwnicy pójścia do urn argumentowali, że w referendum chodzi nie tylko o uchylenie konkretnych zapisów ustawy 40/2004, ale że sprawa dotyczy tak

Por. E. Silvestrini, Procreazione medicalmente assistita: che fare prima e dopo il referendum, Milano 2005, s. 89-92. 
naprawdę decyzji „za” lub „przeciw” odnośnie do przekształcania życia i samego człowieka, które umożliwia współczesna technika. Eksperymenty na embrionach budzą przerażenie nie tylko u tych, którzy domagają się prawnej ochrony życia od momentu poczęcia, ale także tych, którzy obawiają się, że tego rodzaju praktyki doprowadzą do metamorfozy oblicza istoty ludzkiej ${ }^{8}$.

Zwolennicy uchylenia obowiązującego prawa podkreślali w dyskusji przed referendum, że nie można ograniczać wolności badań naukowych oraz prawa kobiet i mężczyzn do posiadania potomstwa. Argumentowano także, iż jest to ustawa sprzeczna $z$ konstytucją, antyeuropejska, nieprzyjazna kobietom itp. Bardzo poważny zarzut dotyczył rzekomej konfesyjności ustawy 40/2004, tzn. przekonania, że jest to prawo stworzone w oparciu o katolicki paradygmat myślowy ${ }^{9}$.

Warto zauważyć, że włoskie prawo regulujące sztuczne zapłodnienie - jeśli nawet jest uznawane za jedno z najbardziej restrykcyjnych w Europie - nie pozostaje w całkowitej harmonii z nauczaniem Kościoła katolickiego. Nie jest to ustawa „katolicka”, ponieważ moralność katolicka nie akceptuje także sztucznego zapłodnienia homologicznego ${ }^{10}$. W katolickim nauczaniu moralnym podkreśla się dwie podstawowe wartości związane z technikami przekazywania życia: życie istoty ludzkiej powołanej do istnienia i wyłączność jego przekazywania w małżeństwie. W związku z tym sąd moralny o metodach sztucznego przekazywania życia powinien być wydany w odniesieniu do tych wartości.

Nie wolno zapominać, że proces sztucznego zapłodnienia - także w wersji homologicznej - prowadzi do niszczenia wielu ludzkich embrionów. Można przyjąć, że na jedno narodzone dziecko, przy wykorzystaniu metod zapłodnienia pozaustrojowego, przypada ok. 20 uśmierconych istnień ludzkich. W konsekwencji Kościół katolicki odrzuca możliwość stosowania metod sztucznego zapłodnienia także wewnątrz małżeństwa, $\mathrm{z}$ wyjątkiem przypadku, w którym środek techniczny nie zastępuje aktu małżeńskiego, lecz służy jako ułatwienie i pomoc do osiągnięcia jego naturalnego celu. Włoscy katolicy zaangażowali się w obronę ustawy

8 Por. F. FukuYama, Koniec czlowieka. Konsekwencje rewolucji biotechnologicznej, Kraków 2004; J. Habermas, Przyszłość natury ludzkiej. Czy zmierzamy do eugeniki liberalnej?, Warszawa 2003; J. Ratzinger - J. Habermas, Etica, religione e Stato liberale, Brescia 2005.

9 Por. C. Casini, dz. cyt., s. 29-42.

10 „Z pewnością FIVET homologiczny - czytamy w instrukcji Kongregacji Nauki Wiary z 1987 r. Donum vitae - nie jest obciążony wszystkimi przeciwwskazaniami etycznymi, które spotyka się w przekazywaniu życia poza małżeństwem; rodzina i małżeństwo pozostają miejscem narodzenia i wychowania dzieci. Jednakże, zgodnie z tradycyjną nauką dotyczącą dóbr małżeństwa i godności osoby, Kościół jest przeciwny, z moralnego punktu widzenia, sztucznemu zapłodnieniu homologicznemu w probówce. Jest ono bowiem samo w sobie niegodziwe i sprzeczne z godnością rodzicielstwa oraz jednością małżeńską, nawet wówczas, gdyby zrobiło się wszystko dla uniknięcia śmierci embrionu ludzkiego". 
40/2004, ponieważ są przekonani, że obecnie nie istnieją żadne możliwości jej ulepszenia i że w konsekwencji stanowi ona wspólne dobro obywateli ${ }^{11}$.

12-13 czerwca 2005 roku, po wielu miesiącach burzliwej debaty, udało się do urn $25,5 \%$ Włochów, natomiast 74,5\% obywateli nie wzięło udziału w głosowaniu. Był to wyraźny sukces tych sił, które wzywały do powstrzymania się od udziału w referendum. W konsekwencji nie uchylono obowiązującego prawa odnośnie do wykorzystania technik sztucznego zapłodnienia. Warto przypomnieć, że organizatorzy referendum przygotowali cztery pytania. Pierwsze dotyczyło zniesienia ograniczeń odnośnie do badań klinicznych i eksperymentów medycznych z wykorzystaniem ludzkich embrionów. Przeciwnikom ustawy 40/2004 chodziło o poszerzenie możliwości pobierania embrionalnych komórek macierzystych i ich wykorzystania w celach terapeutycznych. Jest to stanowisko tej części naukowców, którzy opowiadają się za powoływaniem do życia nowych embrionów w celu pozyskania embrionalnych komórek macierzystych, zamiast ukierunkowania badań na pobieranie komórek macierzystych od osobników dorosłych. W głosowaniu $88 \%$ tych, którzy udali się do urn opowiedziało się za takim rozwiązaniem, $12 \%$ było przeciw.

Drugie pytanie dotyczyło uchylenia niektórych norm ograniczających dostęp do technik sztucznego zapłodnienia. Chodziło o zakaz powoływania do życia in vitro więcej niż trzech embrionów i nakaz wszczepienia ich do łona matki. Zwolennicy referendum kwestionowali także zasadę, że dostęp do technik sztucznego zapłodnienia mają tylko bezpłodne pary małżeńskie lub pary żyjące w innych stałych związkach. W tej kwestii 88,8\% głosujących powiedziało „tak”, natomiast $11,2 \%$ było przeciwnego zdania.

Trzecie pytanie odnosiło się do praw przysługujących wszystkim podmiotom uczestniczącym w procesie sztucznej prokreacji. Chodziło o zniesienie artykułu pierwszego, który przyznaje dziecku poczętemu te same prawa co osobie już narodzonej. Jednocześnie proponowano, aby umoźliwić wykorzystanie technik sztucznego zapłodnienia także dla innych celów niż bezpłodność par małżeńskich. Za uchyleniem norm mówiących o takich prawach, szczególnie prawach dziecka poczętego, opowiedziało się $87,7 \%$ obywateli, a $12,3 \%$ było odmiennego zdania.

Czwarte pytanie dotyczyło uchylenia zakazu sztucznego zapłodnienia heterologicznego. W konsekwencji tego rodzaju zmiany ustawy 40/2004 stałyby się prawnie dopuszczalne następujące techniki rozrodu wspomaganego: zapłodnienie kobiety nasieniem męskim pochodzącym od mężczyzny innego niż jej partner; wszczepienie komórki jajowej pochodzącej od innej kobiety i zapłodnionej nasieniem partnera; wszczepienie komórki jajowej pochodzącej od innej kobiety

11 Por. E. Silvestrini, Dieci domande sulla legge 40/2004 intorno alla „procreazione medicalmente assistita", Roma 2005. 
i zapłodnionej nasieniem obcego mężczyzny. Za taką zmianą w obowiązującym prawie było $77,4 \%$ Włochów, natomiast $22,6 \%$ powiedziało „nie"12.

\section{Pytanie o istotę człowieka}

Ogólnonarodowa debata we Włoszech na temat stosowania technik rozrodu wspomaganego nie zakończyła się wraz z przeprowadzonym referendum. Przeciwnicy ustawy 40/2004 nadal podejmują różnego rodzaju działania na rzecz zmiany obowiązującego prawa. Z kolei ich adwersarze pokazują dobre strony przyjętych wcześniej rozstrzygnięć. Po referendum szczególnie inspirującym zjawiskiem okazała się bardzo ciekawa dyskusja na temat statusu ludzkiego embrionu, która toczyła się na łamach wielu gazet i czasopism. Debata publiczna, która poprzedziła referendum, ukazała ograniczenia współczesnej refleksji filozoficznej na temat statusu embrionu i definicji życia ludzkiego. Pytania dotyczące początku i istoty człowieczeństwa powróciły po referendum ze zdwojoną siłą. W dyskusji zabrali glos najważniejsi włoscy filozofowie i intelektualiści. Zwolennicy referendum (m.in. M. Cacciari, S. Givone, E. Severino, G. Vattimo, S. Veca) zwrócili uwagę szczególnie na to, że ludzki embrion nie ma takich samych praw jak osoba dorosła, natomiast obrońcy ustawy 40/2004 (m.in. D. Antiseri, E. Berti, F. Botturi, V. Possenti, C. Vigna) podkreślili przede wszystkim osobowy charakter dziecka poczętego.

Warto zauważyć, ze przeciwnicy ustawy 40/2004 prezentują bardzo często rozumienie osoby $\mathrm{w}$ różnych odcieniach funkcjonalizmu. Zgodnie $\mathrm{z}$ tym paradygmatem życie ludzkie staje się osobą, gdy pojawia się jedna z funkcji: pamięć, wolność, samoświadomość, zmysł moralny, zdolność komunikacji itp. Redukując osobę do pewnej liczby funkcji, bycie osobowe staje się stopniowalne w zależności od szerokości wypełnianej funkcji. Oznacza to także, że tracąc daną funkcję, przechodzimy ze stanu życia osobowego do bezosobowego. Tego rodzaju rozumienie funkcjonalistyczne prezentował na łamach najbardziej opiniotwórczej gazety we Włoszech „Corriere della Sera” m.in. znany filozof i politolog. Giovanni Sartori ${ }^{13}$. Jego zdaniem tym, co odróżnia życie ludzkiego od życia w ogóle jest samoświadomość. Embrion staje się osobą dopiero wtedy, gdy opuszcza łono matki i zaczyna istnieć samodzielnie. Jego zdaniem nie można racjonalnie uzasadnić tezy, że embrion jest bytem ludzkim. Nie tylko nie jest osobą, ale nie należy także do rodzaju ludzkiego.

12 Por. Dopo i „Referendum” sulla procreazione, „La Civiltà Cattolica” 2 lipca 2005, s. 3.

13 Por. G. SARTori, La vita umana secondo ragione. „Corriere della Sera” 28 lutego 2005, s. 8; Embrione anima e fede. Non si emargini la ragione, „Corriere della Sera” 28 lutego 2005, s. 9; L'embrione e la persona. Contraddizioni dei sostenitori della legge 40, „Corriere della Sera” 11 czerwca 2005, s. 9. 
W podobnych duchu wypowiadał się Massimo Cacciari, profesor estetyki na Uniwersytecie w Wenecji, który uważa za absurdalne przekonanie, że ludzki embrion jest osobą od momentu poczęcia. Jakiekolwiek ograniczanie nauki z zewnątrz przez politykę, religię czy etykę jest nieskuteczne i skazane na niepowodzenie. Jego zdaniem projekt naukowo-techniczny nowożytności jest czymś autonomicznym i nie podlega żadnym ograniczeniom. Jedyna szansa to autonomiczne normy, które rodzą się wewnątrz projektu' ${ }^{14}$. Zbliżoną opinię prezentuje także znany włoski postmodernista Gianni Vattimo, dla którego dziecko poczęte nie jest osobą, ponieważ nie może dochodzić samodzielnie swoich praw ${ }^{15}$.

Z kolei Salvatore Veca, profesor filozofii politycznej na Uniwersytecie w Pawii, twierdzi, że - z jednej strony - pojęcie osoby należy do wspólnego dziedzictwa, ale z drugiej - nie można mówić o osobowym charakterze ludzkiego embrionu. Jego zdaniem polaryzacja stanowisk $w$ tej sprawie będzie się coraz bardziej pogłębiać. Jesteśmy dopiero na początku poważnego sporu filozoficznego i kulturowego, który może zdominować najbliższą przyszłość. W konsekwencji powinniśmy iść za intuicją Maritaina, który uważał, ze także tam, gdzie jest wyraźny brak zgody na poziomie teoretycznym, można znaleźć porozumienie na poziomie praktycznym. W tym kontekście płaszczyzną porozumienia powinna być zasada współżycia społecznego ${ }^{16}$.

Zwolennikiem referendum był także Salvatore Natoli, profesor filozofii politycznej z Mediolanu, dla którego ludzki embrion staje się osobą nie w momencie poczęcia, ale dopiero wraz z pojawieniem się systemu nerwowego. Jego zdaniem nie ma sensu twierdzenie, że embrion jest osobą potencjalną. Albo jest się osobą, albo nie. W konsekwencji można prowadzić badania na embrionach we wczesnej fazie ich rozwoju a nawet wytwarzać ludzkie życie jako materiał do badań naukowych. Natoli uważa, że mamy tutaj do czynienia z zasadą „życie za życie". Perspektywa wynalezienia nowych technik leczenia różnego rodzaju chorób usprawiedliwia uśmiercanie ludzkiego życia w fazie embrionalnej ${ }^{17}$.

Przeciwnikiem ustawy 40/2004 jest także Sergio Givone, profesor estetyki z Florencji, który uważa, że autentycznym „przyjściem na świat” osoby są narodziny, a nie moment poczęcia. Jego zdaniem embrion nie jest tylko swego rodzaju „materiałem ludzkim”, ale stanowi coś ludzkiego, czym trzeba się zaopiekować. To oczywiście nie oznacza, że dziecko poczęte ma te same prawa, co osoba już narodzona. Givone twierdzi, że w przestrzeni współczesnych biotechnologii nie jest możliwa etyka ogólnych zasad, ale jedynie etyka jednostkowości, która oce-

14 Por. Quale etica, quale scienza? - P. Giovanetti rozmawia z M. Cacciarim, „Avvenire 9 lipca 2005, s. 28.

15 Por. G. Vattimo, La vita dellaltro. Bioetica senza metafisica, Lungro di Cosenza 2006, s. 17-21.

16 Por. Separati in laboratorio - A. Zaccuri rozmawia Z S. Veca, „Avvenire” 1 lipca 2005, s. 28.

17 Por. Neppure la scienza cancella il dolore - A. Zaccuri rozmawia z S. Natolim, „Avvenire” 19 czerwca 2005, s. 28. 
nia każdy przypadek w całej jego złożoności. Jego zdaniem sztuczne zapłodnienie i badania na embrionach to nie jest dzisiaj sfera hipotez, ale konkretnie istniejąca rzeczywistość. W sytuacjach konfliktowych trzeba stawiać trudne pytania: co jest bardziej godne dla embrionu: zamrożenie czy wykorzystanie go w celach naukowych ${ }^{18}$.

Remo Bodei, historyk filozofii na Uniwersytecie w Pizie, należy do tych myślicieli, którzy odczuwają zadziwienie nad tajemniczością życia ludzkiego, ale jednocześnie nie uznają osobowego charakteru embrionu. Bodei podkreśla, ze wszyscy jesteśmy gośćmi życia, odrzuca jednak możliwość nazwania embrionu osobą. Jego zdaniem mamy tutaj do czynienia raczej z „projektem życia”. W świecie doskonałym embrion byłby chroniony jako coś, co potencjalnie może stać się osobą. Ale w świecie niedoskonałym, w którym żyjemy pozostaje w konflikcie $z$ innymi potrzebami, których nie można nie doceniać. $Z$ jednej strony nie wolno redukować życia do towaru, $z$ drugiej - trzeba rozumieć dramat tych par małżeńskich, które cierpią z powodu niepłodności ${ }^{19}$.

Zdeklarowanym obrońcą ustawy 40/2004 jest natomiast Vittorio Possenti, profesor filozofii politycznej z Wenecji, który uważa, że sprzeciw wobec referendum był ważnym akordem długiej wojny o godność osoby ludzkiej. Szczególnie doniosłą rolę odegrała w tej walce szkoła personalizmu, która postawiła w centrum problem osoby w epoce, w której komunizm i narodowy socjalizm negowały tego rodzaju kategorię. Possenti zgadza się z opinią Ricoeura, że w naszych czasach umiera personalizm a powraca osoba. Zmierzch nurtu filozoficznego określanego mianem personalizmu nie oznacza wyparowania zainteresowania osobą; przeciwnie - także w obecnym stuleciu rozumienie człowieka jako osoby będzie mieć niezwykle ważne znaczenie ${ }^{20}$.

Profesor filozofii politycznej z Wenecji zauważa, że pojęcie osoby jest czymś pierwotnym i gwarantuje wszystkim ludziom tę samą godność. W takim duchu wypowiada się prawo włoskie, które przyznaje ludzkiemu embrionowi charakter osobowy i uznaje równość praw między dzieckiem poczętym a osobą dorosłą. Zdaniem Possentiego, potrzeba dzisiaj podejścia personalistycznego szczególnie w świecie biotechnologii. Dzięki rozwojowi nauki widzimy coraz wyraźniej, że biegunami egzystencji nie są narodziny i umieranie, ale poczęcie i śmierć. W konsekwencji należy oczekiwać od filozofii pogłębionej refleksji nad osobowym charakterem dziecka poczętego.

18 Por. Cerchiamo unetica per ogni caso - A. Zaccuri rozmawia z S. Givonem, „Avvenire” 19 czerwca 2005, s. 28.

19 Por. Una rivoluzione per letica, M. Cecchietti rozmawia z R. Bodeim, "Avvenire" 26 czerwca 2005, s. 22.

20 Por. V. Possenti, Persona senza pensiero, „Avvenire” 17 czerwca 2005, s. 27. 
Nawet jeśli istniałaby wątpliwość, czy rzeczywiście embrion jest osobą, należałoby stanąć po stronie embrionu: in dubbio pro embrione. Possenti przypomina, że czymś niezwykle istotnym dla bycia osobą jest tożsamość genetyczna. Od momentu poczęcia ludzki embrion posiada własne i niepowtarzalne DNA, które zawiera wiele informacji o jego przyszłości i oznacza, że należy on do rodzaju ludzkiego od momentu poczęcia. Tylko zdecydowana obrona osobowego statusu ludzkiego embrionu może nie dopuścić do tego, aby człowiek stał się wytworem techniki czy zwykłym towarem na rynku, który ulega całkowitemu uprzedmiotowieniu.

W perspektywie profesora filozofii politycznej z Wenecji, umieszczenie w centrum kategorii osoby i pogłębiona refleksja filozoficzna nad osobowym statutem bytu ludzkiego są dzisiaj konieczne, aby chronić życie człowieka przed całkowitą banalizacją i radykalnym uprzedmiotowieniem. Tylko w ten sposób możemy nie dopuścić do tego, aby embrion stał się bytem ludzkim najbardziej wykorzystanym, użytecznym niewolnikiem, przedmiotem konsumpcji lub własnością rodziców czy biotechnologów ${ }^{21}$.

W podobnym duchu zabrał głos znany włoski filozof Dario Antiseri, profesor metodologii nauk społecznych w Uniwersytecie Luiss w Rzymie. Jeśli używamy w celach terapeutycznych zarodkowych komórek macierzystych lub w inny sposób niszczymy ludzkie embriony, naruszamy Kantowską zasadę respektowania cudzego życia, która stanowi swego rodzaju kopię chrześcijańskiego przykazania miłości bliźniego. Jego zdaniem w naszych czasach odkrycia naukowe przestały mieć charakter neutralny moralnie. Wcześniej dobry bądź zły był cel, do którego stosowano dane odkrycie. Dzisiaj mamy diametralnie odmienną sytuację; poszczególne odkrycia możemy oceniać jako dobre bądź złe same w sobie.

Antiseri uważa, że panaceum na wspólczesne wyzwania moralne powinna być myśl liberalna, zakorzeniona w dziedzictwie chrześcijańskim, która kwestionuje absolutyzm władzy państwowej i podkreśla znaczenie wolności oraz odpowiedzialności osoby ludzkiej. „Szacunek dla osoby - pisze Antiseri - świętej i nienaruszalnej, nie pochodzi z filozofii greckiej. W cywilizowanych Atenach małe dziecko odrzucone przez rodzinę oddawano na pożarcie zwierzętom. Chrześcijaństwo wprowadziło pojęcie świętości życia człowieka, stworzonego na obraz i podobieństwo Boga"22.

21 Por. tenże, Agli „schiavi utili” diamo il beneficio del dubbio, „Avvenire” 19 czerwca 2005, s. 28; Filosofi sospesi fra anima e DNA, „Avvenire” 5 lipca 2005, s. 25.

22 Sulla vita non si tratta - P. Lambruschi rozmawia z D. Antiserim, „Avvenire” 2 lipca 2005, s. 26. Por. Etica, scomessa sul futuro - P. Springhetti rozmawia z S. Maffettonem, „Avvenire” 22 lipca 2005, s. 24. 
Carmelo Vigna, profesor filozofii moralnej na Uniwersytecie w Wenecji, poddaje ostrej krytyce funkcjonalistyczne rozumienie osoby ludzkiej. Dzisiaj nasze rozumienie świata jest zdominowane przez to, co widzialne, a życie osobowe ludzkiego embrionu nie jest czymś, co rzuca się nam bezpośrednio w oczy. W konsekwencji należy powrócić do Arystotelesa i jego kategorii potencji. Funkcjonalizm nie wyjaśnia, jak traktować noworodki czy osoby chore. Nie można powiedzieć, że tym, co charakteryzuje osobę jest np. mowa. Kluczem nie jest mowa jako funkcja, ale zdolność mówienia, czyli potencja. Jako byt ludzki, embrion jest aktem; jako dziecko, które mówi jest potencją. Pojęcie osoby ma charakter ontologiczny. Najpierw jest pewna struktura ontologiczna, a dopiero później pojawiają się poszczególne funkcje, które nie mogłyby istnieć bez tej struktury. Osoba jednoczy duszę i ciało, charakteryzuje się jednostkowością i autonomią. Potrzeba etyki, która uznawałaby każdego człowieka jako cel a nie środek naszych działań ${ }^{23}$.

W obronie ludzkiego embrionu jako osoby stanął także Francesco Botturi, profesor antropologii filozoficznej na Uniwersytecie w Mediolanie. Jego zdaniem dyskusja przed referendum pokazała wyraźnie, że dzisiaj zostają zakwestionowane wszystkie wartości, za wyjątkiem jednej: wolności wyboru. Jeśli jednak wolność wyboru opiera się sama na sobie, przyjmuje charakter totalitarny - aż po odmowę uznania osobowego charakteru ludzkiego embrionu. Wolność wyboru nie może jednak stanowić fundamentu życia społecznego, ponieważ w ten sposób zostaje zagrożone dobro wspólne ${ }^{24}$.

Ważnym głosem w dyskusji były słowa E. Bertiego, historyka filozofii z Padwy. Jego zdaniem pojęcie osoby jest ważne dla refleksji filozoficznej. Także dzisiaj kategoria osoby pozostaje najlepszym kandydatem do roli obrońcy praw człowieka. Nie ulega wątpliwości, że najlepszym pojęciem, do którego można się odwołać, aby uzasadnić prawa człowieka, jest ciągle pojęcie osoby. Jego zdaniem filozofowie zamiast spierać się o pojęcie osoby, powinni udzielić odpowiedzi na pytanie, czy embrion posiada prawa czy też nie? Berti uważa, że tak: „Dziecko poczęte, jako jednostka żyjąca rodzaju ludzkiego, z pewnością posiada prawa"25. W konsekwencji ustawa regulująca stosowanie technik sztucznego zapłodnienia musi zająć się także ochroną tych praw. Problem nie polega na tym, żeby zredukować człowieka do towaru, aby móc korzystać z osiągnięć techniki. Problem polega na takim wykorzystaniu techniki, żeby nie naruszać niczyich praw: ani ojca, ani matki, ani dziecka poczętego.

23 Por. L'etica ostre gli steccati - E. Castagna rozmawia z C. Vigna, „Avvenire” 20 lipca 2005, s. 24.

24 Por. Nasconde il potere l'idolo della libertà - A. Zaccuri rozmawia z F. Botturim, „Avvenire” 1 lipca 2005, s. 28.

25 Un diritto da concepire - F. Dal Mas rozmawia z E. Bertom, „Avvenire” 28 czerwca 2005, s. 27. 


\section{Wnioski i podsumowanie}

Prawo obowiązujące obecnie we Włoszech odnośnie do stosowania technik sztucznego zapłodnienia należy uznać za jedno z najlepszych w Europie. Przede wszystkim dlatego, że umieszcza ludzki embrion wśród podmiotów, których prawa powinny być chronione. W konsekwencji dobrze się stało, że referendum przeprowadzone 12-13 czerwca 2005 roku nie doprowadziło do uchylenia ustawy 40/2004. Wydaje się, że analiza włoskiego referendum i dyskusji toczącej się w tym kraju na temat wykorzystania metod rozrodu wspomaganego upoważnia do wyprowadzenia kilku ważnych wniosków.

1. Włoska debata dobrze pokazuje radykalność współczesnego sporu filozoficznego o osobowy status ludzkiego embrionu. Z jednej strony, dzięki niezwykłemu postępowi techniki, wiemy coraz więcej o pierwszych momentach życia ludzkiego płodu. W konsekwencji przekonanie, że po zapłodnieniu powstała nowa istota ludzka, nie jest już sprawą osobistych upodobań czy metafizycznym twierdzeniem, z którym można się spierać, ale zwykłym faktem doświadczalnym. Na naszych oczach współczesna nauka coraz bardziej potwierdza stanowisko tych, którzy bronią osobowego charakteru dziecka poczętego. W konsekwencji ludzki embrion powinien mieć zagwarantowane prawo do życia. Istota ludzka winna być szanowana - jako osoba - od pierwszej chwili swego istnienia. Państwo powinno stać na straży respektowania tego prawa. Dotyczy to także wykorzystania metod sztucznego zapłodnienia. Z drugiej strony, bardzo wielu naukowców, filozofów i ludzi kultury nie zgadza się z takim podejściem i kwestionuje osobowy charakter ludzkiego embrionu. Wydaje się, że polaryzacja stanowisk w tej kwestii będzie się pogłębiać w najbliższych dziesięcioleciach.

2. Spór o ustawę 40/2004 zwrócił uwagę na konieczność oceny etycznej postępu naukowo-technicznego. Współczesne technologie są „środkiem”, który przyczynia się do dobra wspólnego całego społeczeństwa. Nie można zgodzić się jednak z tymi, którzy proponują całkowitą niezależność rozwoju technologicznego od jakiejkolwiek refleksji moralnej. Powinna obowiązywać zasada nie prymatu techniki nad etyką, ale etyki nad techniką. Współczesne technologie nie mogą funkcjonować „poza dobrem i złem”. Radykalna autonomia tej sfery życia może prowadzić do działań szkodzących prawdziwemu dobru człowieka.

3. Włoska debata na temat stosowania metod sztucznego zapłodnienia ukazała niektóre oblicza współczesnego utylitaryzmu. Dla zwolenników tego rodzaju myślenia skoro coś jest technicznie możliwe, staje się jednocześnie moralnie dopuszczalne. Podobnie też wiele par małżeńskich cierpiących na bezpłodność, prezentujących podejście utylitarne, zdaje się nie widzieć zastrzeżeń natury etycznej, kierując się tylko i wyłącznie pragnieniem posiadania dziecka, które często przestaje być $\mathrm{w}$ ten sposób podmiotem $\mathrm{z}$ własną godnością, stając się przede wszystkim przedmiotem pragnień osób dorosłych. W sporze na temat metod rozrodu 
wspomaganego nie wolno zatrzymywać się tylko i wyłącznie na oczekiwaniach i potrzebach rodziców, zapominając o tym, że najważniejsze są prawa dziecka, które powinny być kategorycznie respektowane.

4. Dyskusja wokół wykorzystania technik sztucznego zapłodnienia przypomniała także o bardzo ważnej kwestii: czy poddawać pod głosowanie kwestie etyczne? Wydaje się, że od starożytnych Rzymian powinniśmy uczyć się „wyczucia granicy". Już Cyceron twierdził, że pewne czyny nie stają się dozwolone, jeśli nawet zostały przegłosowane przez większość. Jego zdaniem nigdy nie powinny być poddawane pod głosowanie takie sprawy jak np. kradzież, cudzołóstwo czy naruszenie przysięgi ${ }^{26}$. Posłuszeństwo zasadom prawa naturalnego powinno mieć wyższość nad głosem opinii publicznej i wynikami sondaży.

5. Bardzo pozytywnym rezultatem sporu o zapłodnienie pozaustrojowe jest ożywienie zainteresowania we Włoszech tematyką bioetyczną. W ramach kampanii przedreferendalnej zorganizowano tysiące spotkań i dyskusji. Bardzo wielu filozofów, lekarzy, nauczycieli i prawników zaangażowało się w kampanię informacyjną. To wszystko wyraźnie pogłębiło wiedzę społeczeństwa o podstawowych zagadnieniach bioetycznych. Na dodatek po referendum $w$ wielu regionach Włoch udało się wykorzystać zapał ludzi do stworzenia wielu ważnych i potrzebnych struktur promujących ocenę etyczną szeroko rozumianej sfery biomedycyny i przybliżających społeczeństwu współczesne dylematy moralne.

\title{
Is embryo a person? The dispute about artificial reproduction in Italy
}

\author{
SUMMARY
}

The public dispute about the methods of artificial reproduction has been led in Italy for many years. The most significant principle of the legislation from the year 2004 is the recognition of the human embryo as the human being from the very moment of the conception. The law in Italy forbids, among others, producing human embryos for scientific purposes, freezing and destroying human beings, using the methods of heterological artificial reproduction. The opponents of such legal regulations evoked the nationwide referendum in 2005 which - because of too poor turnout - did not manage to repeal the operative legislation.

${ }^{26}$ Por. I classici? Maestri di moderazione - M. Blondet rozmawia z Martą Sordi, „Avvenire” 29.06.2005, s. 28. 